JRPIPM. Vol. 2 (2018, no. 1 23-29)

Jurnal Riset Pendidikan dan Inovasi Pembelajaran Matematika

ISSN: 2581-0480 (electronic)

URL: journal.unesa.ac.id/index.php/jrpipm

\title{
Validasi Instrumen Modul Komputasi Matematika
}

\author{
Tri Astuti Arigiyati ${ }^{1 *}$, Benidectus Kusmanto ${ }^{1}$, Sri Adi Widodo ${ }^{1}$ \\ ${ }^{1}$ Prodi Pendidikan Matematika FKIP UST \\ *Email: ta.arigiyati@gmail.com
}

\begin{abstract}
ABSTRAK
Tujuan penelitian ini adalah untuk mengetahui kelayakan bahan ajar komputasi matematika yang dikembangkan. Jenis penelitian yang digunakan adalah penelitian pengembangan (Reseach And Development), dengan model pengembangan yang dipilih adalah model pengembangan yang dipilih mengikuti prosedur sederhana yang disarankan oleh Sivasailam Thiagarajan, Dorothy S. Semmel, dan Melvyn I. Semmel yaitu model pengembangan perangkat Four-D Model. Model ini terdiri dari 4 tahap pengembangan yaitu Define, Design, Develop, dan Disseminate atau diadaptasikan menjadi model 4-D, yaitu pendefinisian, perancangan, pengembangan, dan penyebaran. Bahan Ajar yang akan dikembangkan telah divalidasi oleh ahli materi dan ahli modul. Skor rata-rata untuk materi 4,68 dan masuk dalam kriteria sangat baik. Sedangkan skor rata-rata untuk modul 4,84 dan masuk dalam kriteria sangat baik.
\end{abstract}

Kata Kunci: Validasi instrumen, Modul, motivasi belajar

\begin{abstract}
The aim for this study is to examine the appropriateness of of the developed teaching materials in mathematics computation. The method used in this research is Research and Development and using the chosen simple procedure suggested by Sivasailam Thiagarajan, Dorothy S. Semmel, and Melvyn I. Semmel which is Four-D Model. This model consists of four development stages which are Define, Design, Develop, dan Disseminate that is comprised into 4-D. The developed teaching material was validated by the mathematics content expert and module expert. The average score for the topics material is 4,68 and categorized as very good. While the average score for the module is 4,84 and categorized as very good.
\end{abstract}

Kata Kunci: Instrument validation, Module, Learning Motivation

\section{Pendahuluan}

Bahan ajar merupakan salah satu perangkat/bahan dalam proses pembelajaran yang sangat membantu siswa ataupun pembaca dalam memahami materi tertentu. Bahan ajar yang baik tentu selain harus menarik dari segi tampilan maupun konten, maka harus sesuai dengan kebutuhan siswa terhadap materi yang dipelajarinya [1]. Undang-undang Nomor 20 tahun 2003 tentang Sistem Pendidikan Nasional, mengamanatkan 
pembaharuan yang besar dalam sistem pendidikan saat ini. Mengingat pentingnya penguasaan kompetensi matematika untuk kehidupan peserta didik di SD, SMP, SMA dan SMK, telah dikeluarkan Standar Kompetensi Lulusan (SKL) oleh pemerintah melalui permendiknas no 23 tahun 2006 sebagai kelanjutan dari Undang-undang nomor 20 tahun 2003 [2]. Dengan adanya permendiknas no. 23 tahun 2006, diharapkan para guru dalam pembelajarannya di kelas dapat menggunakan metode ataupun strategi yang mampu melibatkan siswa secara aktif di mana pembelajaran disesuaikan dengan tahap perkembangan berpikir siswa, sehingga pembelajaran matematika nantinya akan berdampak positif terhadap prestasi belajar siswa.

Saat pembelajaran komputasi matematika berlangsung, pengajar hanya menggunakan sebuah buku sebagai satu-satunya bahan ajar. Bahan ajar cetak tersebut berisi ringkasan materi, contoh soal dan latihan-latihan soal. Strategi pengorganisasian dan penyampaian isi di dalam bahan ajar tersebut tidak terstruktur dengan baik. Hal itu menyebabkan mahasiswa enggan untuk membacanya apalagi mempelajarinya. Khusus untuk bahan ajar yang berupa bahan cetak seperti modul belum banyak digunakan.

Berdasarkan uraian di atas maka peneliti akan mengembangkan bahan ajar berupa modul yang nantinya dapat digunakan oleh mahasiswa dalam perkuliahan Komputasi matematika agar proses pembelajaran dapat berjalan dengan maksimal. Modul yang dikembangkan sendiri oleh pengajar dapat disesuaikan dengan karakteristik peserta didik. Selain lingkungan sosial, budaya, dan geografis, karakteristik peserta didik juga mencakup tahapan perkembangan peserta didik, kemampuan awal yang telah dikuasai, minat, latar belakang keluarga, dan lain-lain. Pengembangan modul dapat menjawab atau memecahkan masalah ataupun kesulitan dalam belajar [3]. Modul dapat membantu Perguruan Tinggi dalam mewujudkan pembelajaran yang berkualitas. Penerapan modul dapat menyediakan kegiatan pembelajaran lebih terencana dengan baik, mandiri, tuntas dan dengan hasil (output) yang jelas. Modul dapat memfasilitasi peserta didik lebih tertarik dalam belajar, peserta didik otomatis belajar bertolak dari prerequisites, dan dapat meningkatkan hasil belajar [3].

Dalam pembelajaran komputasi matematika materi yang diajarkan menggunakan sotfware Matlab, di mana Matlab sendiri masih dianggap sulit dan kurang familier di kalangan mahasiswa prodi pendidikan matematika UST. Padahal dengan bantuan Matlab kita dapat meyelesaikan semua persoalan matematika dengan cepat dan mudah asalkan sesuai dengan prosedur yang tentukan. Di dalam Matlab semua instruksi harus diketik dengan benar sesuai dengan kaidah-kaidah dalah penulisan Matlab. Hal ini yang terkadang membuat mahasiswa sering melakukan kesalahan saat mengerjakan soal dengan Matlab dan menjadi kurang tertarik dengan pembelajaran ini. Inilah yang menyebabkan motivasi mahasiswa rendah saat mengikuti pembelajaran Komputasi Matematika. Adapun penyebab lain adalah terkendalanya saat mengintal program Matlab pada laptop mahasiswa. Sehingga mahasiswa seringkali memiliki ketergatungan pada teman yang lain saat menggunakan program tersebut. Berdasarkan pengalaman rendahnya motivasi mahasiswa juga dikarenakan sulitnya memahami instruksi-instruksi dalam program Matlab.

Berdasarkan pemikiran dan pertimbangan permasalahan yang dihadapi, peneliti memandang perlu mengembangkan bahan ajar komputasi matematika berupa modul bagi mahasiswa prodi pendidikan matematika UST. Adapun tujuan penelitian ini adalah untuk mengetahui kelayakan bahan ajar yang dikembangkan.

\section{Metode penelitian}


Jenis penelitian yang digunakan adalah penelitian pengembangan (Reseach And Development). Model ini terdiri dari 4 tahap pengembangan yaitu Define, Design, Develop, dan Disseminate atau diadaptasikan menjadi model 4-D, yaitu pendefinisian, perancangan, pengembangan, dan penyebaran.) Model pengembangan perangkat FourDModel disarankan oleh Sivasailam Thiagarajan, Dorothy S. Semmel, dan Melvyn I. Semmel. Tahapan dalam model 4-D dapat digambarkan dalam bagan sebagai berikut: [4]

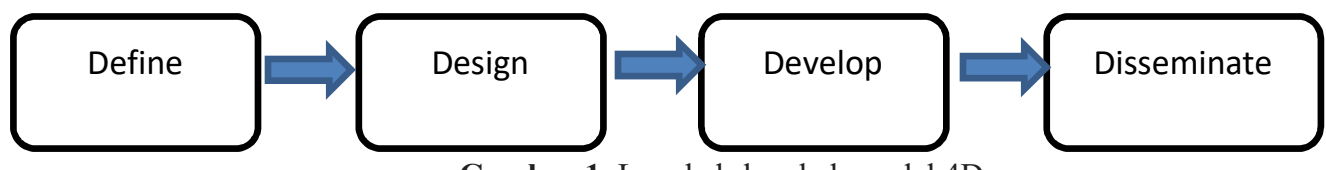

Gambar 1. Langkah-langkah model 4D

\subsection{Define (Pendefinisian)}

Tahap ini dilakukan untuk menetapkan dan mendefinisikan syarat-syarat pengembangan bahan ajar dan perangkat pembelajaran yang mencakup tujuan dan batasan materi pembelajaran. Kegiatan dalam tahap ini terfokus pada: 1) analisis ujung depan, 2) analisis siswa, 3) analisis tugas, 4) analisis konsep, dan 5) analisis tujuan pembelajaran.

\subsection{Design (Perancangan)}

Tahap perancangan bertujuan untuk merancang perangkat pembelajaran. Thiagarajan, dkk (online) membagi perancangan menjadi empat langkah yang harus dilakukan pada tahap ini, yaitu: (1) penyusunan standar tes (criterion-test construction), (2) pemilihan media (media selection) yang sesuai dengan karakteristik materi dan tujuan pembelajaran, (3) pemilihan format (format selection), yakni mengkaji format-format bahan ajar yang ada dan menetapkan format bahan ajar yang akan dikembangkan, (4) membuat rancangan awal (initial design) sesuai format yang dipilih.

\subsection{Develop (Pengembangan)}

Thiagarajan (Online), membagi tahap pengembangan dalam dua kegiatan yaitu: expert appraisal dan developmental testing. Expert appraisalmerupakan teknik untuk memvalidasi atau menilai kelayakan rancangan produk. Dalam kegiatan ini dilakukan evaluasi oleh ahli dalam bidangnya. Saran-saran yang diberikan digunakan untuk memperbaiki materi dan rancangan pembelajaran yang telah disusun. Developmental testing merupakan kegiatan uji coba rancangan produk pada sasaran subjek yang sesungguhnya. Pada saat uji coba ini dicari data respon, reaksi atau komentar dari sasaran pengguna model. Hasil uji coba digunakan memperbaiki produk. Setelah produk diperbaiki kemudian diujikan kembali sampai memperoleh hasil yang efektif.

Dalam konteks pengembangan model pembelajaran, kegiatan pengembangan (develop) dilakukan dengan langkah-langkah sebagai berikut.

- Validasi model oleh ahli/pakar. Hal-hal yang divalidasi meliputi panduan penggunaan model dan perangkat model pembelajaran. Tim ahli yang dilibatkan dalam proses validasi terdiri dari: pakar teknologi pembelajaran, pakar bidang studi pada mata pelajaran yang sama, pakar evaluasi hasil belajar.

- Revisi model berdasarkan masukan dari para pakar pada saat validasi

- Uji coba terbatas dalam pembelajaran di kelas, sesuai situasi nyata yang akan dihadapi.

- Revisi model berdasarkan hasil uji coba

- Implementasi model pada wilayah yang lebih luas. 


\subsection{Disseminate (Penyebarluasan)}

Thiagarajan (Online), membagi tahap dissemination dalam tiga kegiatan yaitu: validation testing, packaging, diffusion and adoption. Pada tahap validation testing, produk yang sudah direvisi pada tahap pengembangan kemudian diimplementasikan pada sasaran yang sesungguhnya. Pada saat implementasi dilakukan pengukuran ketercapaian tujuan. Pengukuran ini dilakukan untuk mengetahui efektivitas produk yang dikembangkan. Setelah produk diimplementasikan, pengembang perlu melihat hasil pencapaian tujuan. Tujuan yang belum dapat tercapai perlu dijelaskan solusinya sehingga tidak terulang kesalahan yang sama setelah produk disebarluaskan. Kegiatan terakhir dari tahap pengembangan adalah melakukanpackaging (pengemasan), diffusion and adoption. Tahap ini dilakukan supaya produk dapat dimanfaatkan oleh orang lain. Pengemasan model pembelajaran dapat dilakukan dengan mencetak buku panduan penerapan model pembelajaran. Setelah buku dicetak, buku tersebut disebarluaskan supaya dapat diserap (diffusi) atau dipahami orang lain dan digunakan (diadopsi) pada kelas mereka.

Data yang digunakan dalam penelitan ini berupa data kualitatif dan data kuantitaif. Data kualitatif dalam penelitian ini digunakan data yang berupa tingkatan penilaian kualitas berdasarkan skala likert yaitu: Sangat Tidak Setuju (STS), Tidak Setuju (TS), Kurang Setuju (KS), Setuju(S), Sangat Setuju (SS). Data kualitatif diambil dengan tujuan untuk mnegetahui kualitas produk yang dihasilkan berdasarkan respon dari peserta didik. Sedangkan data kuantitatif diambil dari lembar validasi yang diisi oleh ahli modul dan ahli materi. Tujuan pengambilan data kuantitatif adalah untuk mengetahui kelayakan perangkat pembelajaran yang dibuat menurut ahli modul dan ahli materi.

Teknik pengumpulan data menggunakan teknik validasi produk. Validasi produk dilakukan untuk menilai perangkat pembelajaran yang dikembangkan baik dari segi materi, tampilan maupun keefektifan. Untuk itu dilakukan validasi ahli modul dan ahli materi. Ahli modul dan ahli materi yang ditunjuk mempunyai keilmuan di bidang Matematika, berpengalaman mengajar minimal 3 tahun dan mempunyai jabatan akademik minimal Asisten Ahli. Hasil dan komentar dari ahli digunakan untuk merevisi produk. Ahli modul dipilih 2 orang yaitu Irham Taufiq,S.Si.,M.Sc. dan Istiqomah, S.Si.,M.Sc. Sedangkan ahli materi adalah Dra. Hj. Esti Harini, M.Si., dan Denik Agustito, S.Si.,M.Sc. Instrumen penelitian yang digunakan adalah angket validasi. Angket validasi tersebut digunakan untuk memperoleh data dari validasi modul dan validasi materi. Berikut ini adalah kisi-kisi angket validasi materi dan validasi modul [5]

Tabel 1. Kisi-kisi Lembar Penilaian Untuk Ahli Materi

\begin{tabular}{|c|c|c|}
\hline No. & Aspek & $\begin{array}{l}\text { Indikator } \\
\end{array}$ \\
\hline \multirow{3}{*}{1} & \multirow{3}{*}{ Kelayakan Isi } & Kesesuaian materi dengan SK dan KD \\
\hline & & Keakuratan Materi \\
\hline & & Pendukung materi pembelajaran \\
\hline \multirow{4}{*}{2} & \multirow{4}{*}{ Kelayakan Penyajian } & Teknik Penyajian \\
\hline & & Pendukung Penyajian \\
\hline & & Penyajian Pembelajaran \\
\hline & & Kelengkapan Penyajian \\
\hline \multirow{6}{*}{3} & \multirow{6}{*}{ Penilaian Bahasa } & Lugas \\
\hline & & Komunikatif \\
\hline & & Dialogis dan Interaktif \\
\hline & & $\begin{array}{lcc}\text { Kesesuaian } & \text { dengan } & \text { Ting } \\
\text { perkembangan peserta didik }\end{array}$ \\
\hline & & Keruntutan dan keterpaduan alur pikir \\
\hline & & Penggunaan istilah, simbol atau ikon \\
\hline
\end{tabular}


Tabel 2. Kisi-kisi lembar Penilaian Untuk Ahli Modul

\begin{tabular}{|c|c|c|c|}
\hline No & Aspek & Komponen & Indikator Komponen \\
\hline \multirow{6}{*}{1} & \multirow{6}{*}{ Kelayakan } & Ukuran Modul & Ukuran Fisik Modul \\
\hline & & \multirow[b]{2}{*}{ Desain Sampul Modul } & Tata Letak Sampul Modul \\
\hline & & & $\begin{array}{l}\text { Huruf yang digunakan } \\
\text { menarik dan mudah dibaca }\end{array}$ \\
\hline & & \multirow{3}{*}{ Desain Isi Modul } & Konsistensi tata letak \\
\hline & & & Unsur tata letak harmonis \\
\hline & & & Unsur tata letak \\
\hline
\end{tabular}

Teknik analisis data yang digunakan adalah teknik analisis deskriptif dengan cara menentukan rata-rata untuk menyatakan kelayakan perangkatpembelajaran ini. Berikut langkah analisis data dari penelitian ini.

\subsubsection{Menentukan rata-rata skor angket}

Data yang telah diperoleh melalui angket oleh ahli modul, ahli materi, dan peserta didik akan diubah menjadi nilai kuantitatif. Dapat dilihat pada tabel di bawah ini

TABEL 3. Aturan Penskoran Angket Validasi Ahli

\begin{tabular}{ll}
\hline \multicolumn{1}{c}{ Keterangan } & Skor \\
\hline STS (Sangat Tidak Setuju) & 1 \\
\hline TS (Tidak setuju) & 2 \\
\hline KS (Kurang Setuju) & 3 \\
\hline S (Setuju) & 4 \\
\hline SS (Sangat Setuju) & 5 \\
\hline
\end{tabular}

Sugiyono, 2013 [8]

\subsubsection{Kriteria dan batas nilai disajikan pada tabel berikut ini}

Tabel 4. Kriteria dan Batas Nilai

\begin{tabular}{|c|c|}
\hline Kriteria & Batas \\
\hline Sangat Tidak baik (STB) & $\bar{X} \leq M \quad 1,5 S D$ \\
\hline Tidak baik (TB) & $1,5 S D<\bar{X} \leq M$ \\
\hline Kurang Baik (KB) & $0,5 S D<\bar{X} \leq M+0,5 S D$ \\
\hline Baik (B) & $M+0,5 S D<\bar{X} \leq M+1,5 S D$ \\
\hline Sangat Baik (SB) & $\bar{X}>M+1,5 S D$ \\
\hline
\end{tabular}

\subsubsection{Proses Analisis Data}

Proses analisis data bertujuan untuk mengetahui tingkat kelayakan dari ahli materi dan ahli modul dengan menentukan skor rata-rata dari lembar validasi yang telah diisi. Skor rata-rata dari validator kemudian dicocokkan dengan tabel kriteria kelayakan modul dan tabel kriteria kelayakan materi perangkat pembelajaran yang dikembangkan. Untuk mengetahui tingkat kelayakan dari peserta didik terhadap modul yang dikembangkan, digunakan tabel kriteria kelayakan peserta didik terhadap modul yang dikembangkan. Adapun hasil validasi modul, validasi materi, serta saran yang diberikan baik dari validator maupun oleh subyek coba dijadikan sebagai acuan dalam penyempurnaan 
modul ini dan hasil perhitungan dari uji coba lapangan utama digunakan sebagai acuan kelayakan produk yang telah dibuat.

\section{Hasil dan Pembahasan}

Bahan ajar merupakan bagian yang sangat penting dari suatu proses pembelajaran secara keseluruhan. Sementara itu, peran utama dosen lebih bersifat fasilisator yang harus senantiasa memfasilitasi setiap perkembangan yang terjadi pada diri mahasiswa selama proses pembelajaran berlangsung. Bahan ajar yang digunakan dalam penelitian ini dikembangkan sedemikian rupa sehigga mahasiswa dimungkinkan mencapai kompetensi matematika yang relevan dengan materi yang dipelajari. Selain itu, fokus mengembangkan bahan ajar diarahkan agar dapat meningkatkan motivasi belajar mahasiswa. Hasil dari validator ahli materi dan ahli modul dapat dilihat pada tabel di bawah ini:

Tabel 5. Hasil Validasi Materi

\begin{tabular}{clcccc}
\hline \multirow{2}{*}{ No } & \multirow{2}{*}{ Aspek yang dinilai } & \multicolumn{2}{c}{ Rerata Validator } & \multirow{2}{*}{ Rata-rata } & \multirow{2}{*}{ kriteria } \\
\cline { 3 - 4 } & Kelayakan Isi & V1 & V2 & & \\
\hline 1 & Kelayakan Penyajian & 4,54 & 4,58 & 4,56 & sangat baik \\
\hline 2 & Penilaian Bahasa & 4,67 & 4,58 & 4,63 & sangat baik \\
\hline 3 & Rata-rata semua komponen & & 4,68 & sangat baik \\
\hline \multicolumn{6}{c}{} \\
\hline
\end{tabular}

Pada tabel 8 dapat dilihat bahwa aspek kelayakan isi, kelayakan penyajian, dan penilaian bahasan mempunyai skor rata-rata 4,68 dan berada dalam kategori sangat baik. Pada aspek kelayakan isi meliputi; 1) kesesuaian materi dengan SK dan KD; 2) keakuratan materi; 3) Kemutahkiran materi. Pada aspek kelayakan penyajian meliputi: 1) Teknik penyajian, 2) pendukung penyajian, 3) penyajian pembelajaran, 4) kelengkapan penyajian. Sedangkan pada aspek Penilaian bahasa yang meliputi: 1) lugas, 2)komunikatif, 3) dialogis dan interaktif, 4) kesesuaian dengan tingkat perkembangan peserta didik, 5) keruntutan dan keterkaitan alur pikir, 6) penggunaan istilah, simbol atau ikon. Hasil akhir dari validasi aspek kelayakan isi masuk dalam kategori sangat baik. Namun ada beberapa hal yang perlu diperbaiki seperti acuan daftar pustaka perlu ditambahkan dan dimutakhirakan. Sedangkan untuk gambar, diagram dan ilustrasi disesuaikan dengan materi yang sedang disampaikan.

Tabel 6. Hasil Validasi Modul

\begin{tabular}{clcccc}
\hline \multirow{2}{*}{ No } & \multirow{2}{*}{ Aspek yang dinilai } & \multicolumn{2}{c}{ Rerata Validator } & \multirow{2}{*}{ Rata-rata } & \multirow{2}{*}{ krieria } \\
\cline { 3 - 4 } & & V1 & V2 & & sangat baik \\
\hline 1 & Ukuran Modul & 5 & 5 & 5 & sangat baik \\
\hline 2 & Desain Sampul Modul & 4,33 & 5 & 4,67 & sangat baik \\
\hline 3 & Desain Isi Modul & 4,67 & 5 & 4,84 & sangat baik \\
\hline & Rata-rata semua komponen & & 4,84 & .
\end{tabular}

Sedangkan pada tabel 9 dapat dilihat bahwa aspek ukuran modul, desain sampul modul, dan desain isi modul pada hasil validasi modul mempunyai skor rata-rata 4,84 dan masuk dalam kategori sangat baik. Beberapa indikator dalam validasi modul meliputi kesesuaian ukuran dengan materi isi modul, warna unsur tata letak harmonis dan memperjelas fungsi, ukuran huruf judul buku lebih dominan, warna judul buku kontras. Modul yang dibuat hendaknya sesuai dengan penulisan modul yang dikeluarkan oleh Departemen Pendidikan Nasional Tahun 2003 sebagaimana dikutip oleh Chomsin S. Widodo dan Jasmadi sebagai berikut: Self instructional (siswa mampu belajar secara 
mandiri) [6][5], Self contained (siswa berkesempatan untuk mempelajari materi pembeajaran secara tuntas), Stand Alone (siswa tidak memerlukan bahan ajar lain), Adaptive (modul menyesuaikan perkembangan ilmu pengetahuan dan teknologi), User friendly (modul menggunakan bahasan dan istilah yang mudah dimengerti). Berdasarkan aspek komponen [7][6], modul yang dibuat sudah memenuhi seluruh komponen, yaitu: Tinjauan mata pelajaran, Pendahuluan, Kegiatan belajar, Latihan, Rambu-ranbu jawaban latihan, Rangkuman, Tes Formatif, Kunci Jawaban Tes Formatif dan Umpan Balik.

Berdasarkan hasil validasi ahli materi dan ahli modul tersebut materi yang disajikan dalam modul sudah layak untuk digunakan. Sedangkan berdasarkan komentar, saran, dan masukan dari beberapa ahli materi dan modul peneliti melakukan berbagai perbaikan antara lain: perbaikan sampul modul, menambahkan beberapa daftar pustaka yang relevan, perbaikan tujuan pembelajaran, perbaikan dalam petunjuk belajar, perbaikan dalam penulisan simbol/notasi dengan equation, dan perbaikan warna grafik yang masih kurang kontras.

\section{Kesimpulan}

Berdasarkan hasil penelitian, pembahasan dan jawaban terhadap masalah peneliti dapat menyimpulkan bahwa (1) hasil penelitian ini adalah perangkat pembelajaran berupa bahan ajar (modul) untuk mata kuliah Komputasi Matematika; (2) bahan ajar (modul) ini layak digunakan. Kelayakan dapat dillihat dari hasil validasi materi dan validasi modul. Validasi materi dan validasi modul dilakukan oleh ahli materi dan ahli modul yaitu dosen Prodi Pendidikan Matematika dengan jabatan akademik minimal Asisten Ahli. Skor ratarata untuk materi 4,68 dan masuk dalam kriteria sangat baik. Sedangkan skor rata-rata untuk modul 4,84 dan masuk dalam kriteria sangat baik.

\section{Daftar pustaka}

[1] Rizki, S., \& Linuhung, N. (2017). Pengembangan Bahan Ajar Program Linear Berbasis Kontekstual dan ICT. AKSIOMA: Jurnal Program Studi Pendidikan Matematika, 5(2), 137-144.

[2] Nomor, U. U. R. I. (20). Tahun 2003.(2003). Sistem Pendidikan Nasional.

[3] Depdiknas. 2008. Panduan Pengembangan Bahan Ajar. Jakarta: Depdiknas.

[4] Zunaidah, F. N., \& Amin, M. (2016). Pengembangan bahan ajar matakuliah Bioteknologi berdasarkan kebutuhan dan karakter mahasiswa Universitas Nusantara PGRI Kediri. Jurnal Pendidikan Biologi Indonesia, 2(1), 19-30.

[5] R Wahyu Berti. (2012). http://eprints.uny.ac.id/9518/6/LAMPIRAN\%201.pdf. diakses tanggal 28 April 2018.

[6] Widodo, C. S. Jasmadi. 2008. Panduan Menyusun Bahan Ajar Berbasis Kompetensi.

[7] Sungkono, dkk. 2003. Pengembangan Bahan Ajar. Yogyakarta: FIP UNY.

[8] Sugiyono. 2013. Metode Penelitian Pendidikan : Pendekatan Kuantitatif, Kualitatif, dan R\&D. Bandung: Alfabeta.

[9] Arcana, I. N. (2013). Bahan Latihan Penelitian Tindakan Kelas (PTK) Penyusunan Proposal. 